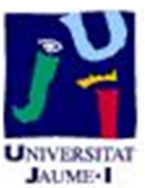

Título artículo / Títol article: The impact of cluster connectedness on firm innovation: $R \& D$ effort and outcomes in the textile industry

Autores / Autors

Francesc Xavier Molina Morales, Manuel Expósito

Langa

Revista:

Entrepreneurship and Regional Development

Versión / Versió:

Versión Pre-print

Cita bibliográfica / Cita bibliogràfica (ISO 690):
MOLINA-MORALES, F. Xavier; EXPÓSITOLANGA, Manuel. The impact of cluster connectedness on firm innovation: R\&D effort and outcomes in the textile industry. Entrepreneurship \& Regional Development, 2012, vol. 24, no 7-8, p. 685704

url Repositori UJI: http://hdl.handle.net/10234/116882 


\title{
THE IMPACT OF CLUSTER CONNECTEDNESS ON FIRM INNOVATION. R\&D EFFORT AND OUTCOMES IN THE TEXTILE INDUSTRY
}

\author{
F. Xavier Molina-Morales \\ Universitat Jaume I, Business Administration and Marketing Department \\ Avda. Vicent Sos Baynat, 12071. Castelló de la Plana, Spain \\ xavier.molina@emp.uji.es \\ Manuel Expósito-Langa \\ (Corresponding author) \\ Universitat Politècnica de València, Business Administration Department \\ Plaza Ferrándiz y Carbonell 3, 03801. Alcoy (Alacant), Spain \\ maexlan@doe.upv.es
}

\begin{abstract}
Recent research into the clustering effect on firms has moved away from a simplistic view to a more complex approach. More realistic and complex causal relationships are now considered when analyzing these territorial networks. Specifically, this paper attempts to analyze how cluster connectedness moderates the relationship of a firm's innovation effort and the results obtained from this effort. We want to question the commonly accepted direct and positive impact of $R \& D$ effort, and moreover, we suggest the existence of a saturation effect and that the level of cluster's inter-connectedness in the cluster moderates this effect. We have developed our empirical study focusing on the Spanish textile industrial cluster. This is a complex manufacturing industry that uses relatively low technology manufacturing and R\&D. Our findings suggest that the degree to which a firm is involved with, or connected to, other firms in the cluster can moderate the effect of the R\&D effort on its innovation results. More generally, we aim to contribute to the discussion on the degree to which firms should be involved in the cluster network in order to operate efficiently and gain the maximum competitive advantages. Our findings have implications both in recent cluster and network literature as well for institutional policy.
\end{abstract}

Keywords: R\&D effort, New product development, Industrial cluster, Textile industry 


\section{INTRODUCTION}

Recent cluster literature seems to be abandoning a rather simplistic perspective on the clustering effect on firms and is moving towards a more realistic and complex consideration of these networks of organizations. This change in direction probably comes as a consequence of the cluster's difficulties in coping with external challenges in a globalized world.

In this context some interesting developments must be mentioned. Firstly, the increasing relevance of the internal diversity between firms in the cluster (Giuliani, 2005; Boshma and Ter Wal, 2007), and secondly, the indirect, non-linear effects of dense internal ties which can alter key features of the cluster's characteristics (Giuliani and Bell, 2005; Waxell and Malmberg, 2007; Molina-Morales and Martínez-Fernández, 2009).

Specifically, this paper attempts to analyze how the level of firm inter-connectedness in a cluster moderates the relationship between a firm's R\&D effort and innovation. Consequently we have defined and operationalized three different concepts: levels of connectedness (the degree to which the firms are involved in the cluster), the R\&D effort (R\&D expenditure) and innovation performance of the firm.

In contrast to the commonly accepted idea of a simple and positive impact of innovation effort on innovation, we suggest a saturation effect and moreover, that the level of firm connectedness within a cluster amplifies this effect.

We have chosen the textile industry as the focus of our empirical study. This is a traditional and complex industry that involves a great number of activities. In recent times, a new segment in the industry, the so-called textile for technological uses has appeared. The production of technical textile implies a higher technological commitment for firms and added-value production. 
We have structured the paper as follows: firstly, we introduce territorial concepts and we argue the proposed causal relationships; following this, we explain the method used and the findings of our analysis; finally, we discuss the implications of the results.

\section{THEORETICAL FRAMEWORK}

Clustered firms receive a huge quantity of knowledge resources from the other members of the cluster. At the same time, to some extent innovation performance depends, as one would expect, on the R\&D effort made by firms. However, it is important to distinguish between innovation effort, which refers to intensity of R\&D activity, and connectedness, which reflects the interactions between firm and cluster. Our study is specifically concerned with how R\&D investment is related to the innovation of the firm, and additionally how local or cluster connectedness moderates this association. The literature that explicitly examines this issue, however, is rare or non-existent. Nevertheless, there is literature from other related fields that can provide us with some insights to contextualize our conceptual developments.

\section{Determinants of innovation in clusters}

Similar to Giuliani and Bell (2005), we understand industrial clusters as geographical agglomerations of economic activities that operate in the same or interconnected sectors. This definition is broadly representative of a large number of territorial notions such as industrial districts (Becattini, 1979) or industrial clusters (Porter, 1990), among others. Research on industrial clusters has underlined the capacity of the clustered firms for knowledge creation and diffusion (Madill et al., 2004; Molina-Morales and Martínez-Fernandez, 2006; Huggins and Johnston, 2010), and they are receiving increased attention in both academic and policy fields. 
In order to properly address cluster innovation determinants, some previous considerations must be taken into account. Clusters should be studied at different levels. There is the system or aggregate level, considering the cluster as a whole, while a second level concerns the individual firm. Additionally, both levels are, in fact, usually interacting (Foss, 1996). Some authors have suggested the existence of systemic learning processes based on the information and knowledge circulating inside the cluster: proximity, the direct formal and informal relationships between individuals and firms, the presence of complementary information and specialized services, and high mobility of the work-force within the district (Tallman et al., 2004; Albino et al., 2006; Waxell and Malmberg, 2007). Moreover, Giuliani (2005) expresses this aggregate level as the cluster's absorptive capacity that she defines as the capacity of the cluster to identify, assimilate and exploit knowledge coming from sources external to the cluster. In spite of the previous lack of clear analysis between innovation and cluster, some contributions are worth mentioning, such as Simmie (2004), who focuses on the nature and extent of links and in particular their contribution to innovation.

In traditional cluster studies, an early interest was to determine the existence of external economies such as labor pooling, specialized suppliers, and knowledge spillovers (Tallman et al., 2004; Albino et al., 2006). More recently, researchers have paid special attention to local knowledge spillovers when examining the agglomeration effects on innovation (Audretsch and Lehmann, 2005; Bell, 2005; Thomson and Fox-Kean, 2005).

To summarize, the implication of being part of a cluster for a firm's innovation can be argued as follows: firstly, previous research emphasizes the importance of knowledge spillovers between incumbent new entrants' geographically proximate organizations (Agarwal et al., 2007). As a result of this knowledge spillover, new entrants continue to develop search processes that are geographically restricted; secondly, the tacit or contextual nature of the 
relevant knowledge for the innovation process also reinforces the importance of the clusters. Rapidly developing technologies are characterized by highly tacit knowledge which cannot be as easily communicated or codified as explicit knowledge (Aharonson et al., 2007). In this context, knowledge transfer depends on interactions such as face-to-face meetings or closed level relationships. The nature of these activities limits geographically the potential for knowledge transfer (Saxenian, 1994; Zucker et al., 1998; Rosenkopt and Almeida, 2003) and causes knowledge decay with distance (Rosenthal and Strange, 2003). These outcomes are especially true when knowledge development refers to the earliest phases of, and unknown potential applications for, new products and services (Jaffe, 1986); thirdly, local network development favours local geographical searches (Saxenian, 1994). In formal or informal networks, individuals embedded in local networks are more likely to develop relationships that are sustainable compared to distant ties which are more costly to maintain (Aharonson et al., 2007). Repeated interaction within these networks leads to the creation of trust (McEvily and Marcus, 2005; Oba and Semerciöz, 2005) and facilitates tacit knowledge development and transfer (Chell and Baines, 2000; George et al., 2001; Levin and Cross, 2004).

Despite systemic effects, individual firms in clusters vary in terms of individual absorptive capacity due to their heterogeneous knowledge-base. Scholars have expressed the need to include firm-level learning into the analysis of clusters (e.g. Bell and Albu, 1999; Maskell, 2001) to understand how firm-level and cluster-level learning processes interact. Moreover, as a consequence of recent changes in clusters, individual firms increase in importance (Morrison, 2008). In fact, authors have argued the importance of the renewal role of individual firms (Varaldo and Ferrucci 1996) and the consolidation of internal heterogeneity in the cluster (Morrison and Rabellotti, 2009). Others such as Belussi and Arcangeli (1998) or Corò and Grandinetti (1999) found evidence that successful clusters are characterized by the presence of a few dynamic firms that develop new products and processes. 
In conclusion, clusters as a whole can generate mechanisms based on internal flows of information and knowledge. However, more and more authors have emphasized the role of the firm's internal resources and in particular those resources related to capacity for innovation (Eraydin and Armatli-Köroğlu, 2005; Molina-Morales and Martínez-Fernández, 2006; Huggins and Johnston, 2010).

\section{The notion of cluster connectedness}

For the purposes of this research we define cluster connectedness as the density of connections in the cluster network. Interactions in clusters can be both formal and informal between organizations. Resources exchange through networks includes work-related resources, such as specific advice and strategic information, but informal networks also transmit social identity (norms) and social support (Podolny and Baron, 1997). The structure of interactions enhances or constrains access to valued resources (Brass, 1984; Ibarra, 1992). Network interactions are a manifestation of the structural dimensions of social capital, and are closely related to the extent of inter-agent resource exchange (Nahapiet and Ghoshal, 1998; Chung et al., 2000). Moreover, Coleman (1988) claims that dense connections between a set of actors govern (constrain) actions in the group and lead to cooperative behavior.

\section{HYPOTHESES}

\section{R\&D effort and innovation}

R\&D activities reflect the individual firm's effort for innovation. The way we have conceptualized this is similar to the absorptive capacity notion. $\mathrm{R} \& \mathrm{D}$ effort is considered to be a decisive factor associated with absorptive capacity (Cohen and Levinthal, 1990). Besides producing new knowledge for innovation and increasing a firm's competitive levels, $R \& D$ is also responsible for generating incentives for learning at the organizational level and 
encouraging interactions with other firms and organizations (Cohen and Levinthal, 1990). Consequently, the R\&D effort made by the firms is a proxy indicator of absorptive capacity.

Usually, the knowledge-base is identified as a combination of skills, training, experience, etc. as well as the in-house knowledge creation effort (Giuliani and Bell, 2005). Cohen and Levinthal (1989) noted the central importance of $R \& D$ investment in order to generate innovation and to develop abilities related to absorptive capacity. In fact, in previous research, such as Evenson and Kislev (1973) and Allen (1984), the authors had already proposed the idea that external knowledge acquisition is a result of internal R\&D investment. These authors analyzed the influence of R\&D effort on accessing the latest technology as well the attempt to assimilate new technology into firms.

According to the above argument, $R \& D$ effort of the individual firm in the cluster may positively affect its capacity to produce new and superior products. Many precedents showing a positive relationship between absorptive capacity and new product development can be found. Absorptive capacity is linked explicitly to organizational learning and its importance in the application of external information (Cohen and Levinthal, 1990). As might be expected, learning is related to product development, particularly learning from external information sources (O'Connor, 1998). Given that product development is a knowledge-intensive process, we therefore expect that higher levels of absorptive capacity will be associated to more effective product development outcomes (Stock et al., 2001). As we have stated above, R\&D investment is related to the knowledge-base of the firm, and consequently to the absorptive capacity of the firm. In fact, previous empirical research has shown a strong correlation between R\&D intensity and indicators of innovation output (for a review: Kamien and Schwarz, 1982). Consequently, and in line with previous literature, we expect a positive relationship between R\&D effort and innovation. 
Additionally, we propose that the effect of $R \& D$ effort varies depending on the amount of R\&D investment. For lower levels of effort, the firm takes advantage of these investments starting new innovative projects. Some innovative projects may require a threshold or minimum level of investment. Positive effects continue throughout the first steps. However there is an inflection or saturation point after which additional increases in R\&D effort do not imply parallel positive results and the effect becomes negative as effort generates costs. Some evidence can be seen in the fact that economies of scale frequently become diseconomies at a certain level of dimension of the infrastructure. For instance, bureaucracy, information loss or employee incentive problems are usually mentioned as limitations of organizational structure growth. It is also relevant that the learning curve reaches a saturation point after which increases are insignificant. Other authors have made similar proposals. These include, among others, Stock et al., (2001) who have analyzed how the R\&D effort and new product development follow a curvilinear inverted-U shape rather than linear relationship.

In clusters, the existence of systemic capacities may generate redundancies with respect to the individual firm's knowledge-base. Since initial investment in the knowledge base can generate additional and complementary effects to the systemic ones, at a certain level of investment, cost would run past, rather than parallel to, benefits. Rather than continuous investment in $R \& D$, firms in clusters should find an optimal balance between internal sources and external sources coming from within the cluster. In this vein, a recent work by Molina-Morales and Martínez-Fernández (2009) proved how intensity of relations and trust in cluster firms can be expressed using an inverted-U shape function.

In conclusion, initially, new investment in $R \& D$ is expected to have a significant beneficial effect on new product development, although diminishing returns are also expected later on. 
The non-linear inverted-U shaped relationship is the one that best captures expectations based on the argument.

Hypothesis 1 . There is an inverted $U$-shaped relationship between $R \& D$ effort and the innovation output of clustered firms.

\section{Cluster connectedness and innovation}

As previously noted, R\&D effort benefits firms, particularly enhancing innovative capacity. Moreover, the membership of a firm to a territorial cluster, as we have already discussed, provides firms with a number of externalities. We propose that benefits from R\&D effort vary according to the level of cluster connectedness of the firm.

Some authors (Coombs et al., 2009) have proposed a direct positive association between network connectedness and innovation. Interactions are channels through which information and resources flow and enable an actor to gain access to other actors' resources. Moreover, interactions dissolve the boundaries between organizations and stimulate the formation of a common interest. Among the advantages are access to information, knowledge and specific resources. Through interactions, firms may increase the depth, breadth and efficiency of the mutual exchange of knowledge. The positive association between connectedness and knowledge acquisition is consistent with the assumptions that learning, particularly that involving difficult-to-transfer information, is aided by intensive, repeated interactions. Thus, connectedness exerts an influence on the future capabilities of firms and, hence, constitutes a factor that helps us to better understand innovation.

In fact, various authors have provided empirical support for this. Several studies (in both intra and inter-organizational relationships) have documented the importance of interactions for the creation and diffusion of innovation (Lane and Lubatkin, 1998; Tsai and Ghoshal, 1998). Consequently, if a firm intensifies its connectedness with other firms in a cluster, it will have 
more opportunities to exchange and combine resources in the network and, as a result, this will have a positive effect on innovation.

Connectedness implies the degree of bonded social capital or embeddedness of the firm within the cluster network, including aspects related to social capital, such as centrality, shared vision etc. Although in general, firms in a cluster benefit from geographically localized knowledge flows or spillovers, as Zucker et al. (1998) argued, providers of the knowledge (diverse supporting organizations such as agencies, universities, professors, and enterprises) are or can be connected ties in a competitive market. Firstly, Yli_renko et al., (2001) found arguments to justify the negative effect of relationships which may suffer from “overembeddedness". Uzzi (1997), for example, proposed that very close relationships insulate small firms from other external sources of information. Secondly, relationship quality (or trust) reaches a very high level; the perceived need to monitor diminishes, decreasing the level of conflict and of intense processing of information. While lowered monitoring and bargaining may reduce the cost of knowledge exchange (Dyer and Singh, 1998), they may also lower the amount of new knowledge acquired. Finally, consistent with this explanation, Nahapiet and Ghoshal (1998) noted that some dimensions of social capital may at times also inhibit exchange and combination processes, constraining rather than enabling learning. Similarly, if trust reaches a very high level, the expectation may exist that information will be provided when needed, so that the incentive to acquire external knowledge is reduced.

According to Huggins and Johnston (2010), social capital investment is more prevalent among firms frequently interacting with actors from within their own region. It is suggested that an over-reliance on social capital forms of network resource investment may hinder the capability of firms to manage their own knowledge networks. It has been concluded that the 
link between a dynamic inter-firm network environment and innovation provides an alternative thesis to that advocating the advantage of network stability.

In consequence, we propose that firms that are strongly connected in the cluster network amplify the effect of R\&D effect on innovation. Initially, the positive effects are amplified. The primary benefits likely to accrue from exploratory research are those that result from novel combinations of local knowledge or from gaining access to specialized resources that are available within a firm's geographical location.

This advantage may include access to specialized laboratory or production equipment required in the R\&D process. Another important factor is access to novel knowledge that is available only through a specific location's idiosyncratic knowledge. With respect to the external cluster sources of resources, it can be said that clusters have developed their own mechanisms to identify external environment changes and facilitate access to new ideas or new opportunities. Giuliani (2005) defines absorptive capacity of the cluster as the capacity to identify, assimilate and exploit knowledge from sources external to the cluster.

The combination of individual and cluster level resources and capacities can produce additional benefits. Firms may enjoy extra advantages when combining external resources with some of their internal resources because of asset stock inter-connectedness or some firms may have some similar resources already, hence enjoying economies of scale asset mass efficiency (Dierickx and Cool, 1989). Consequently, we can expect that the effect of R\&D effort will be higher when a firm is intensely connected to the cluster. In other words, the scope and magnitude of the potential benefits from R\&D effort are likely to be related to the level of a firm's connectedness to the cluster.

As previously discussed, it is also possible to develop a theory proposing a curvilinear relationship between R\&D investment and cluster connectedness on firm innovation. Benefits 
from both may rise only up to a threshold after which point they become negative. Joint additional individual $\mathrm{R} \& \mathrm{D}$ effort and cluster interactions provide no parallel increase in valuable information and consequently in value creation. Ultimately, these diminishing returns could become negative returns. A combination of additional increases in R\&D effort and cluster connectedness amplifies the effects of both on innovation. We suggest that the moderating effect of the firm's cluster connectedness amplifies the curvilinear effect of the R\&D effort on innovation. Thus, we propose:

Hypothesis 2. Degree of connectedness moderates the inverted U-shaped relationship between $R \& D$ effort and innovation of a clustered firm

INSERT FIGURE 1 ABOUT HERE

Figure 1 shows the model of causal relationship proposed in our hypotheses. Firstly, new investment in $R \& D$ is expected to have a significant effect on innovation, although after a saturation point, diminishing returns are also expected. Secondly, a combination of additional increases in $R \& D$ effort and cluster connectedness moderates the curvilinear effect of $R \& D$ effort on innovation.

\section{METHOD}

\subsection{Research setting}

Fashion-led industries such as textile-clothing have been among those most strongly affected by globalization pressures and relocation (Schiattarella 1999). Faced with the increased competition stemming from countries with low labor costs, European firms have reacted with a variety of strategies, including intense policies of productive delocalization aimed at recovering competitiveness in terms of prices, and policies connected to repositioning the national industry in higher segments of the market which are less subject to competition from 
products coming from the aforesaid low-wage countries. The textile industry is one of the most complex manufacturing industries, having an enormous number of possible activities involved, from yarn production to fabric or knitwear for the final customer. Recently, shifts in international markets have caused new developments in this industry. A displacement of the internal low added-value activities to external locations has occurred, and consequently, a substitution of internal activities by new ones producing superior and higher added-value products has taken place. It is worth mentioning that the textile sector has been the focus of many researchers in cluster literature (Guerrieri and Pietrobelli, 2004; Sammarra and Belussi, 2006; Crestanello and Tattara, 2011).

In the textile industry two main traditional segments can be distinguished: clothing and household textiles. A third segment, the so-called textiles for technical use is focused on technological characteristics, with higher R\&D intensity requirements rather than aesthetical or decorative requirements, as is usually the case of textiles for home or clothing. The frequent destination of these products is other industries and markets rather than the traditional ones. In recent years, international trade liberalization and the introduction of new production technologies have allowed firms to increase the productivity of the sector and to move from existing to higher quality and added value activities. At the same time a reduction in employment occurred due to the delocalization of labor intensive activities. In particular, there is an increase in the international trade of yarns and other lower cost textile products which are now manufactured in developing countries. This has affected the domestic sector, leading to a continuous reduction of production levels and number of firms.

\subsection{Sample collection and data sources}

The textile industry in the Valencian region is located in an industrial cluster in the counties L'Alcoià, El Comtat and L'Alt Vinalopo in the province of Alicante and in La Vall d'Albaida 
in the province of Valencia. According to the trade association ATEVAL, in 2008 about 32,100 people were employed, with a value of production of 1,825 million Euros accounting for respectively $17.6 \%$ and $17.5 \%$ of the total Spanish sector. The main products are the socalled home textiles, however, in recent years technical textile production has increased considerably.

In 2008 , the textile and clothing industry in Spain constituted a total of $6.5 \%$ of industrial employment, 3\% of GDP and 5.3\% of Spanish industrial exports. The textile and clothing industry has traditionally played a central role in the Spanish pattern of specialization. In addition, this sector is one of the most representitive of the local agglomerations in Spain. The textiles sector reveals the highest degree of geographical concentration.

The empirical study has drawn on the population of the firms belonging to the Valencian textile industrial cluster, in Spain. Questionnaires were used as a primary data source and the fieldwork was carried out over the period from July to October in 2008. Identification of firms was done using ATEVAL's database complemented by two additional databases: ARDAN ${ }^{1}$ and $\mathrm{SABI}^{2}$ which allowed us also to control some of the questionnaire answers. Prior to questionnaire distribution we ran a pilot questionnaire with five selected respondents that we considered representative of the whole sample. Finally, the questionnaire responses were obtained by personal interviews. Respondents were required to have a global knowledge of the firm, and in particular R\&D investment and product portfolio of the firm. General

\footnotetext{
${ }^{1}$ ARDAN Valencia region is a database published by IMPIVA a public industrial policy agency at regional level that provides financial and product information about all firms located in the Valencia region. We used industrial activities segments involved with textile processes.

${ }^{2}$ SABI is a directory of Spanish and Portuguese firms that collects general information and financial data. In the case of Spain, it covers more than $95 \%$ of the firms of the 17 Spanish regions with total yearly revenues over 360,000-420,000€.
} 
managers account for $52.7 \%$ of the questionnaire respondent profile and $47.3 \%$ are other members of management teams.

Sampling validity

The initial group of firms were members of ATEVAL, the national trade association of textile firms, using the 2008 listing. We have 96 complete, accepted questionnaires accounting for $27 \%$ per cent of the population. Using the Student's $t$-test we checked for possible bias between sample and population. To do that, we carried out two different tests, referring to size and age of the firms. Table 1 shows that there was no bias between sample and population.

\section{INSERT TABLE 1 ABOUT HERE}

\subsection{Variables}

\section{Dependent Variable}

\section{Innovation, creation of new products}

We are aware of the difficulties in assessing the innovation results of a firm. Different approaches can be used to measure a firm's innovative capacity. For several reasons many firms do not protect this knowledge by means of patents (Grant, 1996) so instead, we follow the recommendation of Tusman and Nadler (1986) who related innovation to new product, service or process creation by business units. Consequently in the context of our research we have associated innovation with the degree to which a firm dedicates its production to technical textiles, since we can assume that this segment implies new products (or a line of new products) for the textile industrial cluster. Moreover, this indicator has been used previously in research on this industry (Expósito-Langa et al., 2011). 
To avoid limitations of self-assessment of innovation results by firms we have run a control of measures by a panel of experts, following Bell's suggestions (2005). We have carried out indepth interviews with a panel of experts from the Agrupación Empresarial Textil Alcoyana, a key provider of knowledge and advanced services for the textile firms in the cluster.

As a result of the meeting with experts we have elaborated an indicator using a 1-5 Likert scale to assess the innovation of a firm. Then we have computed the bivariant correlation between the expert indicator and the firms' answers, resulting in a satisfactory correlation at $.672(\mathrm{p}<.01)$, thereby we consider that the indicator we used in our study captures adequately the innovation results of the firm.

Definitively, this variable attempts to capture the capacity of a firm to generate new products. In the context of our research we have characterized creation of new products with the degree to which the products of the firm are focused on the technical textiles segment. We understand that products for this segment can be considered to be new products (or a range of new products) for the firms in the industrial districts. The variable was made operational through the item: (1) What percentage of the products your firm produces are for the technical textile segment?

Independent variable

$R \& D$ Intensity

Using the same approach that has been used in some research, including among others Cohen and Levinthal, (1990), Mowery et al. (1996) and Tsai (2001), we have measured this variable taking the average of the relationship ( $R \& D$ expenditures / Total revenue) over the last three years.

\section{Connectedness}


The connectedness variable was developed based on the idea of collaboration (Cockburn and Henderson, 1998). To measure this, we assessed the degree of connectivity inside the network. We asked about the dependence of the firm with respect to other businesses in the cluster in obtaining relevant resources and advice for decision-making and problem-solving (McEvily and Zaheer, 1999; Rowley et al. 2000). Additionally, we asked respondents about shared goals and common assets with other firms in the same cluster (Rowley et al., 2000). Finally we obtained values for the intensity in social interactions used by Tsai and Ghoshal (1998) and Yli_renko et al. (2001). We used a 1-5 point Likert scale.

An exploratory factor analysis was performed to identify the multi-item scale for the construct of connectedness. A Cronbach's $\alpha$ value of 0.876 was obtained and the results of the factor analysis reported that the Barlett test of sphericity was significant $($ Chi-square $=341.09$; $\mathrm{df}=$ 3 ; sig. $=.000)$ and the Kaiser-Meyer-Olkin $(\mathrm{KMO})$ measure was greater than $0.6(\mathrm{KMO}=$ .622). Therefore, it was appropriate to proceed with a factor analysis (Coakes and Steed, 2001). A one factor solution was obtained with varimax rotation and $82.42 \%$ of variance extracted from the overall variance.

\section{Control variables}

To complete our model we included some control variables. These non-hypothesized variables can be expected to be associated with the dependent variable. The inclusion of these variables allows us to isolate the independent variables' effect in the model.

Size is usually used as a control variable, as has been reviewed at length in Kamien and Schwarz (1882) or Mowery et al. (1996) all of whom state that size and innovation are associated. Consequently, it is to be expected that larger firms will invest more in R\&D activities. To avoid a high correlation between total revenues and R\&D intensity, size was established using total employees. Finally, age was also included, since some authors have 
suggested that in industrial districts temporary evolution affects performance (Glasmeier, 1991; Pouder and St. John, 1996).

\section{RESULTS}

In Table 2, we present basic descriptive statistics and Pearson's correlation for all variables. As expected, the correlations matrix shows high correlation between innovation and R\&D intensity. However, what was most noticeable was the lack of significance between the control variables and $R \& D$ intensity.

INSERT TABLE 2 ABOUT HERE

\subsection{Regression models}

To test the hypotheses we ran a stepwise hierarchical regression approach to assess the explanatory power of each set of variables. Moreover, to deal with possible multi-colinearity each variable included in the interaction terms was mean centered (Aiken and West, 1991). The models are as follow:

Model 1: Innovation $=\alpha_{1}+\beta_{1}$ Firm Size $+\beta_{2}$ Firm Age $+\beta_{3}$ Connectedness

Model 2: Innovation $=\alpha_{1}+\beta_{1}$ Firm Size $+\beta_{2}$ Firm Age $+\beta_{3}$ Connectedness $+\beta_{4}$ R\&D Intensity $+\beta_{5} R \& D$ Intensity ${ }^{2}$

Model 3: Innovation $=\alpha_{1}+\beta_{1}$ Firm Size $+\beta_{2}$ Firm Age $+\beta_{3}$ Connectedness $+\beta_{4}$ R\&D Intensity

$+\beta_{5} \mathrm{R} \& \mathrm{D}$ Intensity $^{2}+\beta_{6} \mathrm{R} \& \mathrm{D}$ Intensity $\mathrm{x}$ Connectedness $+\beta_{7} \mathrm{R} \& \mathrm{D}$ Intensity $^{2} \mathrm{x}$ Connectedness 
Model 1 presents the base case controlling firm size, firm age and connectedness. Model 2 examines the proposed inverted U shape, and finally, Model 3 introduces interaction terms reflecting the moderating influence of connectedness on $R \& D$ intensity.

Model 2 reports the regression results for Hypothesis 1. The curvilinear model attempts to validate the existence of a non-linear relationship between innovation effort and new innovation in cluster firms. In order to statistically justify the proposed inverted $U$ shape, we run a regression analysis with curvilinear estimation to find a quadratic relation.

The results of Model 2 can be seen in Table 3. An ANOVA analysis confirms the possible existence of a significant correlation between variables. In our case, the F-statistic result confirms the significance of the variance of the dependent variable through the quadratic model. Moreover, results confirm the significant relationship between R\&D effort and innovation adjusted to the inverted-U form. The regression coefficients, both innovation effort and innovation effort squared have some significance. It is also noticeable that the sign of the innovation effort squared is negative, indicating an inverted $U$ shape relationship. This means increasing values of the innovation variables effort run parallel with the increasing values for innovation, however, at a certain point, additional increases are negatively associated with innovation. Thus, the positive effect of R\&D effort is eroded by over-use of it.

Table 3 also shows that neither size nor age are significantly associated with innovation. In fact, these results were expected, since previous literature reveals that size is not a relevant factor because there is an intense division of labor among specialized firms. For instance, Russo (1985) argued that economies of scale are not significant in these contexts. Regarding age, some authors (e.g. Pouder and St. John, 1996) suggested that as a result of public and private incentives in the creation of new clusters and certain characteristics of their evolution, age is negatively related to firm innovation. Along the same lines, Glasmeier (1991) pointed 
out that production systems and innovation are time-dependent in industrial districts. In spite of these suggestions, at least in our case, this negative effect of the age cannot be confirmed, since age was not significantly related to a dependent variable. An explanation can be found in the fact that the district is now in a mature phase of its development where even the new firms enjoy similar conditions with respect to already existing firms.

\section{INSERT TABLE 3 ABOUT HERE}

In Hypothesis 2 we assess the moderating role of connectedness on R\&D intensity. As we show in Table 3, model 3 indicates that the first-order interaction affects innovation positively, whereas their second-order interaction relates negatively to innovation. To gain more insight into the interaction effects in Hypothesis 2, we plot the relationship in Figure 2.

It is often extremely interesting to determine whether or not an effect remains constant across different contexts, groups of individuals, and values of the independent variable. The strength of a direct effect may depend linearly upon the value of a moderator. We know that R\&D effort influences innovation and we also need to know if this effect remains constant across diverse degrees of connectedness. In figure 2, to visualize the influence of the moderator effect, we split the connectedness variable into two groups (high and low) and estimate the effect for both levels. The figure shows how at lower and upper levels of connectedness the effect of R\&D effort on innovation has the same curve however the effect is amplified. Following this, we can show that connectedness strengthens the positive effect of R\&D intensity on innovation, increasing the saturation level.

\section{INSERT FIGURE 2 ABOUT HERE}

The main insights of the study are twofold. Firstly, we look at the non-linear effect of the absorptive capacity of the firm (measured by R\&D effort) on innovation. After a certain 
threshold, the influence of R\&D effort on innovation appears to become negative. R\&D effort can be considered a good thing for innovation but it is possible to invest "too much" time energy and money in these activities. Secondly, the degree of connectivity of the firm in the cluster modifies and amplifies this curvilinear effect.

These two main results of the study are supported by, and also enlarge on, some of the previous research to be found in clusters and network literature. However, what could be the main contribution of the study comes from the approach used. Previously a lot of support can be found for a positive impact of $R \& D$ effort on knowledge and innovation of the firm (Evenson and Kislev, 1973; Allen, 1984). Moreover, some precedents in related literature seem to justify a curvilinear effect. The economies of scale often become diseconomies after a certain point; the learning curve reaches a point of cumulative production quantity where improvements are insignificant (Stock et al., 2001). Furthermore, in recent times, several studies have proved how the effect of density and strength of the ties in networks (cluster connectedness) also describes an inverted-U shape relationship (Molina-Morales and Martínez-Fernandez, 2009 or Lechner et al., 2010).

Our own findings, however, go beyond previous studies since we have contextualized the effect of $R \& D$ effort when firms belong to a territorial network. Since the degree of connectedness of the firm in the network moderates the effect of the R\&D effort, a firm must consider the combination of effects in order to improve its innovation performance,

\section{CONCLUSIONS}

Our research has analyzed the role played by $R \& D$ effort on innovative capacity in the context of industrial clusters. Thus, we can state that both concepts are positively associated, since $R \& D$ effort as a component of the knowledge base of the firm enhances the absorptive 
capacity to acquire and exploit external sources of knowledge, and consequently the creation of new products.

The findings of this research are in line with the work by Stock et al. (2001), showing a good fit for the inverted-U shape function. In consequence, we can point out that a great amount of resources invested in R\&D by the firm does not necessarily imply a systematic development of innovation. There will usually be a saturation level after which decreasing returns occur.

In order to continue enhancing their innovative capacity firms may search for other organizational variables, for instance specialization, formalization, management attitude, internal communication, etc. Moreover, other structural moderators can be found such as the type of industry, entrepreneurial environment or the type of innovation (Calantone et al., 1997).

The implications of these findings are extremely relevant in the context of clusters. Individual firms should design their internal endowment of resources taking into account the interactions with aggregate or systemic endowment of resources, rather than simply cumulatively increasing them. In order to avoid inefficient investment, firms should analyze possible synergetic combinations between in-house and cluster-level resources and capacities. Sometimes, the individual knowledge-base is additive and sometimes complementary to the cluster-level resources and capacities. In this vein, the recent discussion on the role played by geographical proximity in knowledge transmission in clusters becomes relevant.

Although it is not a direct implication of our findings, our results suggest that an excess of connectedness in the cluster context becomes negative in terms innovation results for firms. This idea was previously suggested by Uzzi (1997) who argued that in a dense network additional ties are unlikely to generate non-redundant information. Additional increases in the number of direct ties to an actor reduce performance because the cost of maintaining an 
additional tie exceeds its information benefits (Burt, 1992). In the same vein, Sparrowe et al., (2001) proved the negative relationship between the density of ties between groups or units and their performance. Moreover, this conclusion is in agreement with much of the recent cluster and network literature (Molina-Morales and Martinez-Fernandez, 2009; Lechner et al, 2010). However, our contribution goes further since we analyze the combined effect of internal individual capacities and external ones. Our findings suggest the effect of connectedness can regulate the effect of the internal effort of the firm.

In fact, recently, the concept of proximity has been presented as a multidimensional concept not exclusively associated to physical or geographical proximity (Boschma, 2005). From this point of view physical distance is not the only or main factor explaining the spatial diffusion of knowledge (Staber, 2007). Recent work has proved that knowledge diffusion is influenced by factors other than proximity, including among others, institutional, social or cognitive distances (Breschi and Lissoni, 2001; Rallet and Torre, 2005). One of the consequences of the relevance of the non-physical dimensions of proximity is that knowledge is unevenly distributed among members of an industrial cluster (Giuliani and Bell, 2005). Authors argue the existence of sub-networks inside the districts, with significant differences in terms of network structure characterization (Giuliani, 2005; Giuliani and Bell, 2005; Morrison and Rabellotti, 2009). In fact, different knowledge bases mean firms perform different roles in knowledge networks.

Finally, our findings have relevant policy implications. Prior to any further consideration, it must be noted that policy implications and recommendations are suitable not only for governmental policy makers, but also for the wide range of locally oriented institutions and organizations which are supporting and governing the industrial system. Following Parrilli's (2009) line of analysis, we focused on institutions that this author has depicted with the policy 
inducement arguments. The general idea from our findings suggests that location within the cluster boundaries is not enough to gain innovative capacity. Therefore, local units need to develop a wide range of collaborative networks within and beyond the cluster boundaries, and also correctly combine them with the internal resources to absorb and apply the information externally obtained. This evidence implies, from cluster policy perspective, that governmental programs should assist internal capacities building, and reinforce those cluster dynamics that enlarge the firm's original knowledge base (for example, local or industry labor mobility).

\section{Limitations and further research}

This research suffers from some limitations which are related to the peculiarities of the case considered. This article examines the textile industry, a complex manufacturing industry, having a large number of possible activities involved. In spite of recent changes and improvements, this industry has relatively intensity in terms of technology and R\&D. The case characteristics may affect the potential generalization of the conclusions since it is obviously quite different from more knowledge-based sectors. However, we can identify our case within the broader context of labor-intensive and low-tech industries. Along with Maskell (1998) we see the relevance of these industries even in countries or areas with comparatively high labor cost. According to this author in some of these industries the exposure to international competition has led to a trend towards spatial agglomeration where the importance of proximity is derived more from the ease of communication and exchange of knowledge. Thus, the connectedness to the cluster can increase the value of the innovative effort in these categories of industries.

Focusing on one single industry may allow us a better control of specific aspects of this industry and has allowed us to particularize a measurement of innovation based on new products. It would be difficult to directly compare new-product based innovation between 
different industries. However, it must be accepted that studying a particular group of firms may introduce bias into conclusions, limiting potential generalizations to other contexts. In particular with respect to scales used to measure variables, these obviously can be subject to improvement to better capture the construct we want to measure. In consequence, a refinement of the scale will be an objective of our future research.

Other limitations come from the way innovation effort has been made operational. In fact some authors have considered this variable as multidimensional, thus needing additional indicators. Moreover we found difficulties in conceptualizing diversification capacity. We were concerned with a very specific type of capacity that firms in a cluster develop to produce a specific superior product.

To address these possible limitations and as further research we propose the application of the model to other contexts and clusters and to carry out the corresponding comparison analyses.

To sum up, we consider this research to be a contribution to a better understanding of the relationship between innovation effort and innovation results in the particular context of the industrial cluster. Our findings allow us to describe a more realistic relationship between innovation effort, connectedness and performance. Nevertheless, this is initial tentative research, as a first step towards further research incorporating additional explanatory factors.

\section{REFERENCES}

Agarwal, R., Audretsch, D. and Sarkar, M. B. 2007 The process of creative construction: knowledge spillovers, entrepreneurship, and economic growth, Strategic Entrepreneurship Journal, 1, 3-4: 263-286.

Aharonson, B. S., Baum, J. A. C. and Feldman, M. P. 2007 Desperately seeking spillovers? Increasing returns, industrial organization and the location of new entrants in geographic and technological space, Industrial and Corporate Change, 16: 89-130.

Aiken, L. S. and West, S. G. 1991 Multiple regression: Testing and interpreting interactions (Sage: Newbury Park, CA). 
Albino, V., Carbonara, N. and Giannoccaro, I. 2006 Innovation in industrial districts: An agent-based simulation model, International Journal of Production Economics, 104: 30-45.

Allen, T. J. 1984 Managing the Flow of Technology: Technology Transfer and the Dissemination of Technological Information within the R\&D Organization, (Cambridge, MA: MIT Press).

Audretsch, D. B. and Lehmann, E. E. 2005 Does the knowledge spillover theory of entrepreneurship hold for regions?, Research Policy 34: 1191-1202.

Becattini, G. 1979 Dal settore industriale al distretto industriale. Alcune considerazioni sull'unità di indagine in economia industriale, Revista di Economia e Politica Industriale, 1: 7-14.

Bell, G. G. 2005 Clusters, networks, and firm innovativeness, Strategic Management Journal, 26, 3: 287-295.

Bell, M. and Albu, M. 1999 Knowledge Systems and Technological Dynamism in Industrial Clusters in Developing Countries, World Development, 27, 9: 1715-1734.

Belussi, F. and Arcangeli, F. 1998 A typology of networks: Flexible and evolutionary firms, Research Policy, 27, 4: 414-428.

Boschma, R. A. 2005 Proximity and innovation: a critical assessment, Regional Studies 39, 1: $1-14$.

Boschma, R. A. and Ter Wal, A. L. J. 2007 Knowledge networks and innovative performance in an industrial district: The case of a footwear district in the south of Italy, Industry and Innovation, 14: 177-99.

Brass, D. J. 1984 Being in the right place: a structural analysis of individual influence in an organization, Administrative Science Quarterly, 29, 518-539.

Breschi, S. and Lissoni, F. 2001 Knowledge spillovers and Local innovation systems: A critical Survey, Industrial and Corporate Change, 10, 4: 975-1005.

Burt, R. S. 1992 Social structure of competition, in Nohria, N. and Eccles, R. G. (Eds.) Networks and organizations: Structure, form and action.( Harvard Business School Press, Boston, MA) pp. 445-470.

Calantone, R. J., Schmidt, J. B. and DiBendetto, C. A. 1997 New product activities and performance: the moderating role of environmental hostility, Journal of Product Innovation Management, 14, 3: 179-189.

Chell, E. and Baines, S. 2000 Networking, entrepreneurship and microbusiness behaviour, Entrepreneurship \& Regional Development, 12, 3: 195-215.

Chung, S., Singh, H. and Lee, K. 2000 Complementary, Status Similarity and Social Capital as Drivers of Alliance Formation, Strategic Management Journal, 21: 1-22

Coakes, S. and Steed, I. 2001 SPSS Analysis Without Anguish, Version 10.0 (Sydney: John Wiley). 
Cockburn, I. M. and Henderson, R. M. 1998 Absorptive capacity, coauthoring behavior, and the organization of research in drug discovery, Journal of Industrial Economics, 46: 157-182.

Cohen, W. and Levinthal, D. 1989 Innovation and learning: The two faces of R\&D, Economic Journal, 99: 569-596.

Cohen, W. and Levinthal, D. 1990 Absorptive capacity: A new perspective on learning and innovation, Administrative Science Quarterly, 35, 1: 128-152.

Coleman, J. S. 1988 Social capital in the creation of human capital, American Journal of Sociology, 94: 95-120.

Coombs, J., Deeds, D. and Ireland, R. 2009 Placing the choice between exploration and exploitation in context: a study of geography and new product development, Strategic Entrepreneurship Journal, 3, 3: 261-279.

Corò, G. and Grandinetti, R. 1999 Evolutionary patterns of Italian industrial districts, Human Systems Management, 18: 117-129.

Crestanello, P. and G. Tattara 2011 Industrial Clusters and the Governance of the Global Value Chain. The Romania-Veneto Network in Footwear and Clothing, Regional Studies, 45, 2: $187-203$

Dierickx, I. and Cool, K. 1989 Asset stock accumulation ans sustainability of competitive advantage, Management Science, 35: 1504-1511.

Dyer, J. and Singh, H. 1998 The relational view: Cooperative strategy and sources of interorganizational competitive strategy,. Academy of Management Review, 23: 660-679.

Eraydin, A. and Armatli-Köroğlu, B. 2005 Innovation, networking and the new industrial clusters: the characteristics of networks and local innovation capabilities in the Turkish industrial clusters, Entrepreneurship \& Regional Development, 17, 4: 237-266.

Evenson, R. E. and Kislev, Y. 1973 Research and productivity in wheat and maize, Journal of Political Economy, 81: 1309-1329.

Expósito-Langa, M., Molina-Morales, F. X. and Capó-Vicedo, J. 2011 New product development and absorptive capacity in industrial districts: A multidimensional approach, Regional Studies, 45, 3: 319-331.

Foss, N. J. 1996 Higher-Order Industrial Capabilities and Competitive Advantage, Journal of Industry Studies, 3: 1-20.

George, G., Wood, D. R., Jr and Khan, R. 2001 Networking strategy of boards: implications for small and medium-sized enterprises, Entrepreneurship \& Regional Development, 13, 3: 269-285.

Giuliani, E. 2005 The Structure of Cluster Knowledge Networks: Uneven and Selective, not Pervasive and Collective, DRUID Working Paper n. 05-11.

Giuliani, E. and Bell, M. 2005 The micro-determinants of meso-level learning and innovation: evidence from a Chilean wine cluster, Research Policy, 34, 1: 47-68. 
Glasmeier, A. 1991 Technological discontinuities and flexible production networks: The case of Switzerland and the world watch industry, Research Policy, 20: 469-485.

Grant, R. M. 1996 Prospering in dynamically-competitive environments: Organizational capability as knowledge integration, Organization Science, 7, 4: 375-387.

Guerrieri, P. and Pietrobelli, C. 2004 Industrial districts' evolution and technological regimes: Italy and Taiwan, Technovation, 24, 899-914.

Huggins, R. and Johnston, A. 2010 Knowledge flow and inter-firm networks: The influence of network resources, spatial proximity and firm size, Entrepreneurship \& Regional Development, 22, 5: 457-484.

Ibarra, H. 1992 Homophilv and differential returns: Sex differences in network structure and access in an advertising firm, Administrative Science Quarterly, 37: 422-447.

Jaffe, A. B. 1986 Technological opportunity and spillovers of R\&D: evidence from firms' patents, profits, and market value, American Economic Review, 76: 984-1001.

Kamien, M. I. and Schwarz, N. L. 1982 Market structure and innovation, (Cambridge: Cambridge Univ. Press).

Lane, J. and Lubatkin, M. 1998 Relative absorptive capacity and interorganizational learning, Strategic Management Journal, 19: 461-477.

Lechner, C., Frankenberger, K. and Floyd, S.W. 2010 Task contingencies in the curvilinear relationships between intergroup networks and initiative performance, Academy of Management Journal, 53, 4: 865-889.

Levin, D. Z. and Cross, R. 2004 The strength of weak ties you can trust: the mediating role of trust in effective knowledge transfer, Management Science, 50: 1477-1490.

Madill, J., Haines, G. and Riding, A. 2004 Networks and linkages among firms and organizations in the Ottawa-region technology cluster, Entrepreneurship \& Regional Development, 16, 5: 351-368.

Maskell, P. 1998 Low-tech Competitive Advantages and the Role of Proximity: the Danish Wooden Furniture Industry, European Urban and Regional Studies, 5, 2: 99-118.

Maskell, P. 2001 Towards a knowledge-based theory of the geographical cluster, Industrial and Corporate Change, 10, 4: 921-943.

McEvily, B. and Marcus, A. 2005 Embedded ties and the acquisition of competitive capabilities, Strategic Management Journal, 26, 11: 1033-1055.

McEvily, B. and Zaheer, A. 1999 Bridging ties: A source of firm heterogeneity in competitive capabilities, Strategic Management Journal, 20, 12: 1133-1156.

Molina-Morales, F.X. and Martínez-Fernández, M. 2006 Industrial districts: something more than a neighbourhood, Entrepreneurship \& Regional Development, 18, 6: 503-524. 
Molina-Morales, F. X. and Martínez-Fernández, M. T. 2009 Too much love in the neighborhood can hurt: How an excess of intensity and trust in relationships may produce negative effects on firms, Strategic Management Journal, 30: 1013-1023.

Morrison, A. 2008 Gatekeepers of knowledge within industrial districts: who they are, how they interact, Regional Studies, 42, 6: 817-835.

Morrison, A. and Rabellotti, R. 2009 Knowledge and information networks: Evidence from an Italian wine local system, European and Planning Studies, 17, 7: 983-1006.

Mowery, D. C., Oxley, J. E. and Silverman, B. S. 1996 Strategic alliances and interfirm knowledge transfer, Strategic Management Journal, 17: 77-91.

Nahapiet, J. and Ghoshal, S. 1998 Social capital, intellectual capital, and the organizational advantage, Academy of Management Review, 23, 2: 242-266.

O'Connor, G. C. 1998 Market Learning and radical innovation: a cross comparison of eight radical innovation projects, Journal of Product Innovation Management, 15, 2: 151-166.

Oba, B. and Semerciöz, F. 2005 Antecedents of trust in industrial districts: an empirical analysis of inter-firm relations in a Turkish industrial district, Entrepreneurship \& Regional Development, 17, 3: 163-182.

Parrilli, M. D. 2009 Collective efficiency, policy inducement and social embeddedness: Drivers for the development of industrial districts, Entrepreneurship \& Regional Development, 21, 1: 1-24.

Podolny, J. M. and Baron, J. N. 1997 Resources and relationships: Social networks and mobility in your workplace, American Sociology Review, 62: 673-693.

Porter, M. E. 1990 The competitive advantage of the nations, (The Free Press, New York).

Pouder, R. and St. John, C. 1996 Hot spots and blind spots: geographic clusters of firms and innovation, Academy of Management Review, 21, 4: 1192-1225.

Rallet, A. and Torre, A. 2005 Proximity and localization, Regional Studies, 39, 1: 47-59.

Rosenkopf, L. and Almeida, P. 2003 Overcoming local search through alliances and mobility, Management Science, 79: 751-766.

Rosenthal, S. S. and Strange, W. C. 2003 Geography, industrial organization, and agglomeration, Review of Economics and Statistics, 85: 377-393.

Rowley, T., Behrens, D. and Krackhardt, D. 2000 Redundant governance structures: An analysis of structural and relational embeddedness in the steel and semiconductor industries, Strategic Management Journal, 21: 369-386.

Russo, M. 1985 Technical Change and Industrial District: the Role of Interfirm Relations in Growth and Transformation of Ceramic Tile Production in Italy, Research Policy, 14: 329343. 
Sammarra, A. and Belussi, F. 2006 Evolution and relocation in fashion-led italian districts: evidence from two case-studies, Entrepreneurship \& Regional Development, 18, 6: 543-562.

Saxenian, A. 1994 Regional advantage: Culture and competition in Silicon Valley and Route 128 (Harvard University Press, Cambridge, MA).

Schiattarella, R. 1999 La delocalizzzione internazionale: problemi di definizione e delimitazione. Un'analisi per il settore del Made in Italy, Economia e Politica Industriale, 103.

Simmie, J. 2004 Innovation and Clustering in the Globalised International Economy, Urban Studies, 41, 5-6: 1095-1112.

Sparrowe, R., Liden, R., Wayne, S. and Kraimer, M. 2001 Social networks and the performance of individuals and groups, Academy of Management Journal, 44, 2: 316-325.

Staber, U. 2007 Contextualizing research on social capital in regional clusters, International Journal of Urban and Regional Research, 31, 3: 505-521.

Stock, G. N., Greis, N. P. and Fischer, W. A. 2001 Absorptive capacity and new product development Journal of High Technology Management Research, 12, 1: 77-91.

Tallman, S., Jenkins, M., Henry, N. and Pinch, S. 2004 Knowledge, clusters, and competitive advantage, Academy of Management Review, 29, 2: 258-271.

Thompson, P. and Fox-Kean, M. 2005 Patent citations and the geography of knowledge spillovers: a reassessment, American Economic Review, 95: 450-460.

Tsai, W. 2001 Knowledge transfer in intraorganizational networks: Effects of network position and absorptive capacity on business unit innovation and performance, Academy of Management Journal, 44: 996-1004.

Tsai, W. and Ghoshal, S. 1998 Social capital and value creation: The role of intrafirm networks, Academy of Management Journal, 41, 4: 464-478.

Tushman, M. L. and Nadler, D. A. 1986 Organizing for innovation, California Management Review, 28, 3: 74-92.

Uzzi, B. 1997 Social structure and competition in interfirm networks. The paradox of embeddeness, Administrative Science Quarterly, 42: 35-67.

Varaldo, R. and Ferrucci, L. 1996 The evolutionary nature of the firm within industrial districts, European Planning Studies, 4, 1:27-34.

Waxell, A. and Malmberg, A. 2007 What is global and what is local in knowledge-generating interaction? The case of the biotech cluster in Uppsala, Sweden, Entrepreneurship \& Regional Development, 19, 2: 137-159.

Yli_renko, H., Autio, E. and Sapienza, J.H. 2001 Social capital, knowledge acquisition, and knowledge exploitation in young technology-based firms, Strategic Management Journal, 22: 587-613. 
Zucker, L. G., Darby, M. R. and Armstrong J. 1998 Geographically localized knowledge: spillovers or markets?, Economic Inquiry, 36: 65-86.

Figure 1. The relationship between Connectedness, R\&D effort and Innovation

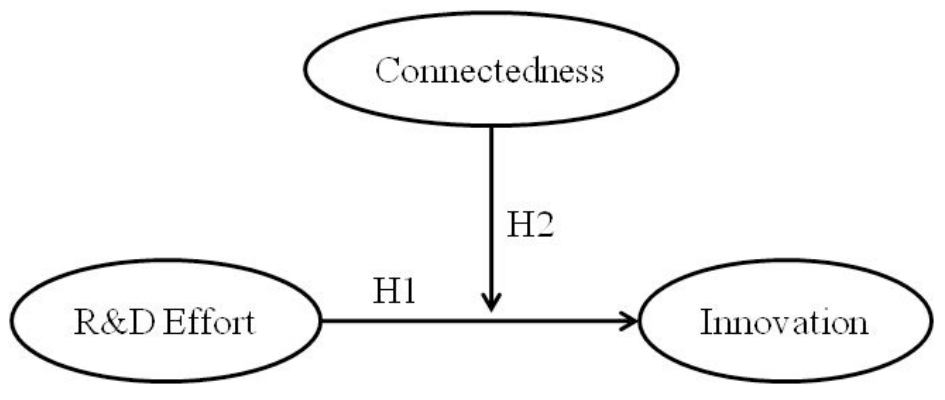

Figure 2. Curvilinear effects

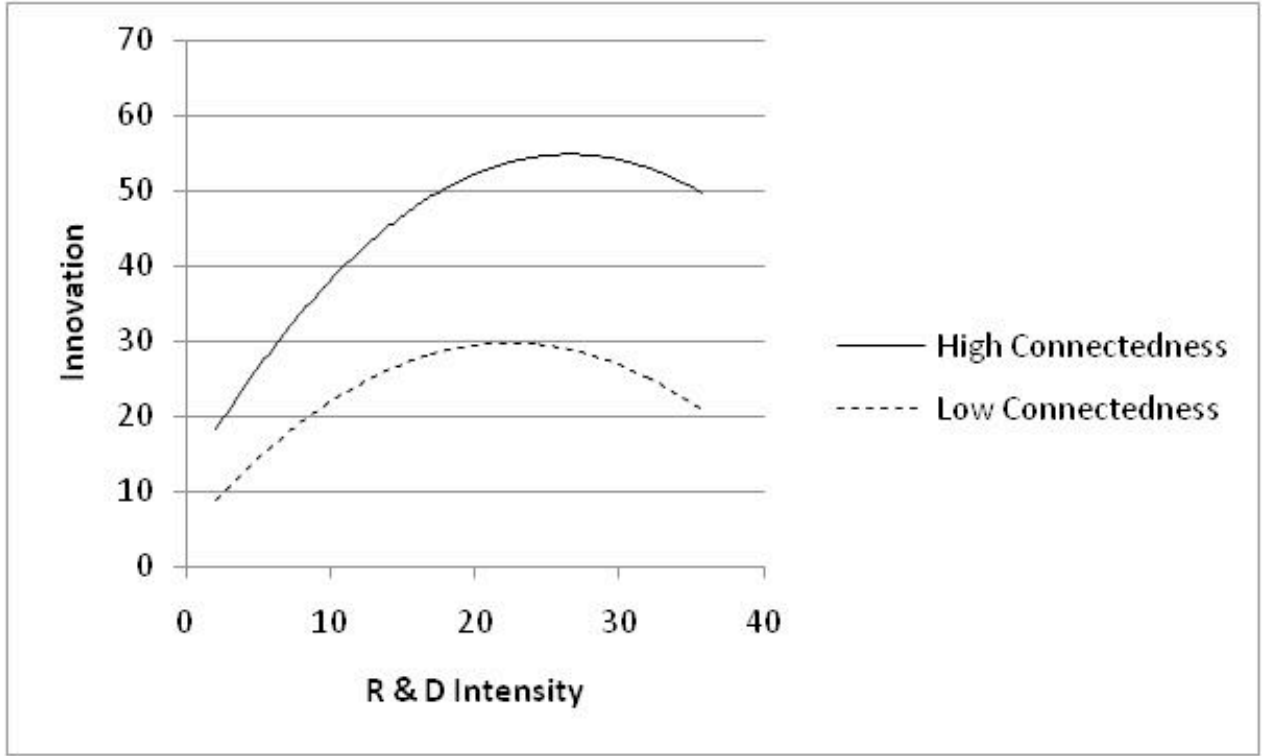

Table 1.Student's t-test

\begin{tabular}{ccccc}
\hline & $\begin{array}{c}\text { Test } \\
\text { value }\end{array}$ & $\mathbf{t}$ & $\begin{array}{c}\text { Sig. } \\
\text { (bilateral) }\end{array}$ & $\begin{array}{c}\text { Means } \\
\text { difference }\end{array}$ \\
\hline Size & 28 & 1.640 & .105 & 6.324 \\
$\mathrm{Age}$ & 1984 & -1.025 & .309 & -1.392 \\
\hline $\mathrm{N}=96$ & & & &
\end{tabular}


Table 2. Descriptive statistics and correlations of the measurements

\begin{tabular}{|c|c|c|c|c|c|c|c|c|}
\hline $\begin{array}{r}\text { 1.1.1.1.1.1 } \\
\text { riables }\end{array}$ & $\boldsymbol{\alpha}$ & Mean & S.D. & 1 & 2 & 3 & 4 & 5 \\
\hline (1) Innovation & - & 19.59 & 30.484 & 1 & & & & \\
\hline (2) Firm Size & - & 34.32 & 33.174 & .161 & 1 & & & \\
\hline (3) Firm Age & - & 23.391 & 11.676 & -.075 & $.345^{* *}$ & 1 & & \\
\hline (4) Connectedness & .876 & 2.526 & .959 & .168 & .189 & -.093 & 1 & \\
\hline (5) R\&D Intensity & - & 8.767 & 6.362 & $.329 * *$ & -.029 & -.144 & .042 & 1 \\
\hline
\end{tabular}

Table 3. Regression results of models

\begin{tabular}{|c|c|c|c|}
\hline Dependent variable: Innovation & & & \\
\hline & M1 & M2 & M3 \\
\hline \multicolumn{4}{|l|}{ Direct effects } \\
\hline Firm Size & $\begin{array}{l}.049 \\
(.389)\end{array}$ & $\begin{array}{l}.082 \\
(.559)\end{array}$ & $\begin{array}{l}.028 \\
(.191)\end{array}$ \\
\hline Firm Age & $\begin{array}{c}-.100 \\
(-.789)\end{array}$ & $\begin{array}{c}-.326 \\
(-1.663)\end{array}$ & $\begin{array}{c}-.040 \\
(-.168)\end{array}$ \\
\hline Connectedness & $\begin{array}{c}.260^{*} \\
(2.216)\end{array}$ & $\begin{array}{c}.321 \\
(1.452)\end{array}$ & $\begin{array}{c}-.284 \\
(-779)\end{array}$ \\
\hline$R \& D$ intensity & & $\begin{array}{l}.791 * * \\
(1.871)\end{array}$ & $\begin{array}{c}1.409 * * * \\
(2.696)\end{array}$ \\
\hline R\&D intensity ${ }^{2}$ & & $\begin{array}{c}-.302 * \\
(-1.032)\end{array}$ & $\begin{array}{l}-.712^{* *} \\
(-1.978)\end{array}$ \\
\hline \multicolumn{4}{|l|}{ Interaction effects } \\
\hline R\&D intensity x Connectedness & & & $\begin{array}{l}.630 * * \\
(1.978)\end{array}$ \\
\hline R\&D intensity ${ }^{2} x$ Connectedness & & & $\begin{array}{c}-.407 * \\
(-1.579)\end{array}$ \\
\hline Model $F$ & 2.196 & $9.985 * * *$ & $7.976 * * *$ \\
\hline Adjusted $R^{2}$ & .047 & .378 & .398 \\
\hline$R^{2}$ change & - & $.331 * * *$ & $.020 *$ \\
\hline
\end{tabular}

$\mathrm{N}=96 ; * * * \mathrm{p}<.01 ; * * \mathrm{p}<.05 ; * \mathrm{p}<.1$

Standardized regression estimates ( $t$-values) 